\title{
The interaction of native DNA with $\mathrm{Zn}$ (II) and $\mathrm{Cu}$ (II) complexes of 5-triethyl ammonium methyl salicylidene orto-phenylendiimine
}

\author{
Arturo Silvestri ${ }^{\text {a,*}}$, Giampaolo Barone ${ }^{\text {a }}$, Giuseppe Ruisi ${ }^{\text {a }}$, Daniele Anselmo ${ }^{\text {a }}$, \\ Serena Riela ${ }^{b}$, Vincenzo Turco Liveri ${ }^{\mathrm{c}}$ \\ a Dipartimento di Chimica Inorganica e Analitica "S. Cannizzaro", Università di Palermo, Viale delle Scienze, Parco d'Orleans II, \\ Edificio 17, 90128 Palermo, Italy \\ b Dipartimento di Chimica Organica "E. Paternò”, Università di Palermo, Viale delle Scienze, Parco d'Orleans II, Edificio 17, 90128 Palermo, Italy \\ c Dipartimento di Chimica Fisica "F. Accascina", Università di Palermo, Viale delle Scienze, Parco d'Orleans II, Edificio 17, 90128 Palermo, Italy
}

Received 10 October 2006; received in revised form 31 January 2007; accepted 31 January 2007

Available online 14 February 2007

\begin{abstract}
The interaction of native calf thymus DNA with the $\mathrm{Zn}(\mathrm{II})$ and $\mathrm{Cu}(\mathrm{II})$ complexes of 5-triethyl ammonium methyl salicylidene ortophenylendiimine $\left(\mathrm{ZnL}^{2+}\right.$ and $\left.\mathrm{CuL}^{2+}\right)$, in $1 \mathrm{mM}$ Tris- $\mathrm{HCl}$ aqueous solutions at neutral $\mathrm{pH}$, has been monitored as a function of the metal complex-DNA molar ratio by UV absorption spectrophotometry, circular dichroism (CD) and fluorescence spectroscopy. The results support for an intercalative interaction of both $\mathrm{ZnL}^{2+}$ and $\mathrm{CuL}^{2+}$ with $\mathrm{DNA}$, showing $\mathrm{CuL}^{2+}$ an affinity of approximately 10 times higher than $\mathrm{ZnL}^{2+}$. In particular, the values of the binding constant, determined by UV spectrophotometric titration, equal to $7.3 \times 10^{4}$ and $1.3 \times 10^{6} \mathrm{M}^{-1}$, for $\mathrm{ZnL}^{2+}$ and $\mathrm{CuL}^{2+}$, respectively, indicate the occurrence of a marked interaction with a binding size of about 0.7 in base pairs. The temperature dependence of the absorbance at $258 \mathrm{~nm}$ suggests that both complexes strongly increase the DNA melting temperature (Tm) already at metal complex-DNA molar ratios equal to 0.1 . As evidenced by the quenching of the fluorescence of ethidium bromide-DNA solutions in the presence of increasing amounts of metal complex, $\mathrm{ZnL}^{2+}$ and $\mathrm{CuL}^{2+}$ are able to displace the ethidium cation intercalated into DNA. A tight $\mathrm{ZnL}^{2+}-\mathrm{DNA}$ and $\mathrm{CuL}^{2+}-\mathrm{DNA}$ binding has been also proven by the appearance, in both metal complex-DNA solutions, of a broad induced CD band in the range $350-450 \mathrm{~nm}$. In the case of the $\mathrm{CuL}^{2+}$-DNA system, the shape of the $\mathrm{CD}$ spectrum, at high $\mathrm{CuL}^{2+}$ content, is similar to that observed for $\psi$-DNA solutions. Such result allowed us to hypothesize that $\mathrm{CuL}^{2+}$ induces the formation of supramolecular aggregates of DNA in aqueous solutions.
\end{abstract}

(C) 2007 Elsevier Inc. All rights reserved.

Keywords: Copper; DNA; Intercalations; Schiff bases; Zinc

\section{Introduction}

Over the past decades there has been substantial interest in the deoxyribonucleic acid (DNA) binding properties toward a number of metal complexes, with the aim to develop novel reagents which can control genetic information and or prevent the growth and replication of cancerous cells through the inhibition of transcription [1-5]. The necessary requisites that such complexes should obvi-

\footnotetext{
${ }^{*}$ Corresponding author. Fax: +39091427584.

E-mail address: asilves@unipa.it (A. Silvestri).
}

ously possess, are to be stable and inert in biological environment and water-soluble. Among the metals with established biological properties, great attention has been devoted to copper and zinc complexes, for several reasons. Firstly, together with iron, they are the most abundant trace elements present in biological systems and several metalloproteins contain one or both elements. Moreover, their derivatives are usually toxic and therefore have often been used as biocides. In addition, it is worth to note that copper and zinc differ for one atomic number unit and, at a given oxidation state of the metal, the different number of d electrons can be used to explain differences of their 
analogous compounds in, for example, magnetic, spectroscopic, redox or structural properties [6].

Copper and zinc complexes have been found to interact with DNA through different binding modes [7-9]. In particular, copper(II) complexes in the presence of oxidizing or reducing agents are able to cleave DNA. Research on DNA cleavage by synthetic copper complexes is of considerable interest because of their efficacy as anti-tumour agents [10-13].

The interaction among DNA and metal complexes containing multidentate aromatic ligands, with square planar $\mathrm{N}_{4}$ or $\mathrm{N}_{2} \mathrm{O}_{2}$ coordination, has been throughly considered [14-16]. Indeed, such compounds have some favourable features [15-19]: the ligand can be attached to the metal in a controlled manner; binding to DNA is usually accompanied by marked absorbance changes in the UV-vis frequency range and, sometimes, fluorescence emission too, due to excitation of charge transfer transitions. These properties, together with the analysis of the optical and thermal behaviour of DNA in the presence of these metal complexes, provide a convenient handle for monitoring the binding process.

Salen, the anion of the Schiff base $\left[N, N^{\prime}\right.$-ethylenebis(salicylideneimine)], $\mathrm{H}_{2}$ Salen, and ligands obtained by its chemical modifications fall in this class of compounds. Indeed, they are characterized by a planar area with extended $\pi$ system, coordinate metal atoms via a square planar $\mathrm{N}_{2} \mathrm{O}_{2}$ system and their complexes experience electronic transitions in the UV-vis range.

We have previously reported on the interaction of native calf thymus DNA with $\mathrm{Fe}^{\mathrm{III}}($ Salen)Cl [20]. The results obtained have been interpreted in terms of an electrostatic binding of $[\mathrm{Fe}(\mathrm{Salen})]^{+}$cation and the phosphate groups of DNA.

ESR measurements on DNA-fibres [21] have revealed that the orientation of water-soluble cationic Salen-type Schiff base complexes of copper(II), relative to the DNA axis, changes by modification of the chain length bridging the two imino nitrogens in the complex. Such measurements allowed to conclude that the 1,2-phenylenediamine bridge enables the metal complex to intercalate DNA. Recently, it has also been reported that a new copper(II) complex, $\quad \mathrm{Cu}(o \text {-VANAHE })_{2}, \quad(\mathrm{VANAHE}=2(o$-vanillinamino)1-hydroxyethane) [22] binds to DNA and presents interesting nuclease activity.

The synthesis of copper complexes with several ligands has been extensively reported, and those factors that determine their application in biological processes deeply investigated. On the contrary, the study of the interaction of zinc(II) complexes of Schiff bases with DNA has received less attention. Since $\mathrm{H}_{2}$ Salen and most of its derivatives are usually sparingly soluble in water [23], the synthesis of water-soluble derivatives is an important first step for possible applications in biological systems. To this aim, an increasing number of papers have been reported to introduce charged groups to the salicylidene or diamine moieties [24-27]. In particular, it has been reported that cationic Schiff base complexes of copper(II) strongly interact with DNA by groove or intercalating binding mode, depending on the size and the nature of the substituents [27].

To further investigate the role of the metal ion in the interaction with DNA, in the present paper, we have synthesized the $\mathrm{Cu}(\mathrm{II})$ and $\mathrm{Zn}(\mathrm{II})$ complexes of 5-triethyl ammonium methyl salicylidene orto-phenylendiimine [21] and studied their interaction with native calf thymus DNA in aqueous solution.

\section{Materials and methods}

The complexes (Fig. 1) were synthesized [21] by the reaction of 5-(triethylammoniummethyl)salicylaldehyde chloride, 1,2 phenylendiamine and copper(II) or zinc(II) acetate in a 2:1.1:1 molar ratio, in doubly distilled water, and isolated as perchlorate salts. The 5-(triethylammoniummethyl) salicylaldeide chloride ligand was prepared from 5-chloromethyl salicylaldeide [28] and triethylamine in THF. The products were characterized by elemental analysis, UV spectroscopy, and/or ${ }^{1} \mathrm{H}$ NMR and ${ }^{13} \mathrm{C}$ NMR.

5-Chloromethyl salicylaldeide: ${ }^{1} \mathrm{H}$ NMR $(300.13 \mathrm{MHz}$, $\mathrm{CDCl}_{3}$, s, singlet; d, doublet; m, multiplet) $\delta(\mathrm{ppm}): 4.59$ $\left(\mathrm{s}, 2 \mathrm{H}, \mathrm{CH}_{2}\right) ; 6.99-7.02(\mathrm{~d}, 1 \mathrm{H}, J=8.4 \mathrm{~Hz}, \mathrm{Ar}) ; 7.54$ $7.59(\mathrm{~m}, 2 \mathrm{H}, \mathrm{Ar}) ; 9.90(\mathrm{~s}, 1 \mathrm{H}, \mathrm{OH}) ; 11.07(\mathrm{~s}, 1 \mathrm{H}, \mathrm{CHO})$; ${ }^{13} \mathrm{C}$ NMR (75.47 MHz, $\left.\mathrm{CDCl}_{3}\right) \delta(\mathrm{ppm}): 45.19 ; 118.30$; $120.34 ; 129.19 ; 133.58 ; 137.27 ; 161.61 ; 196.12$.

5-(Triethylammoniummethyl) salicylaldeide chloride: ${ }^{1} \mathrm{H}$ NMR (300.13 MHz, $\mathrm{CD}_{3} \mathrm{OD}$, t, triplet; q, quartet; dd, double doublet) $\delta(\mathrm{ppm}): 1.33-1.38(\mathrm{t}, 9 \mathrm{H}, J=6.8 \mathrm{~Hz}$, $\left.\mathrm{CH}_{3}\right) ; 3.11-3.23\left(\mathrm{q}, 6 \mathrm{H}, J=7.0 \mathrm{~Hz}, \mathrm{CH}_{2}\right) ; 4.41(\mathrm{~s}, 2 \mathrm{H}$, $\left.\mathrm{CH}_{2}\right) ; 7.01-7.04(\mathrm{~d}, 1 \mathrm{H}, J=9.5 \mathrm{~Hz}, \mathrm{Ar}) ; 7.59-7.64(\mathrm{dd}$, $1 \mathrm{H}, \quad J=2.5 \mathrm{~Hz}, J=10.0 \mathrm{~Hz}, A \mathrm{Ar}) ; 7.81-7.82(\mathrm{~d}, 1 \mathrm{H}$, $J=2.5 \mathrm{~Hz}, \quad$ Ar $) ; 10.08 \quad(\mathrm{~s}, \quad 1 \mathrm{H}, \quad \mathrm{CHO}) ;{ }^{13} \mathrm{C} \quad \mathrm{NMR}$ (75.47 MHz, $\left.\mathrm{CD}_{3} \mathrm{OD}\right) \delta$ (ppm): 7.06; 52.48; 59.51; 118.45; $118.88 ; 122.24 ; 136.32 ; 140.21 ; 162.97 ; 194.56$.

$\mathrm{CuC}_{34} \mathrm{H}_{46} \mathrm{~N}_{4} \mathrm{O}_{10} \mathrm{Cl}_{2}\left(\mathrm{CuL}\left(\mathrm{ClO}_{4}\right)_{2}\right)$ : (a) Anal. Calcd: C, $50.72 ; \mathrm{H}, 5.76 ; \mathrm{N}, 6.96 ; \mathrm{Cl}, 8.81$; found: $\mathrm{C}, 50.22 ; \mathrm{H}$, $5.69 ; \mathrm{N}, 6.86 ; \mathrm{Cl}, 8.59$; (b) electronic absorption in Tris$\mathrm{HCl}, \mathrm{pH}$ 7.5: $\left[\mathrm{nm}\left(\varepsilon, \mathrm{M}^{-1} \mathrm{~cm}^{-1}\right)\right]: 252\left(5.35 \times 10^{4}\right), 304$ $\left(2.49 \times 10^{4}\right), 334\left(1.95 \times 10^{4}\right), 397\left(1.79 \times 10^{4}\right)$.

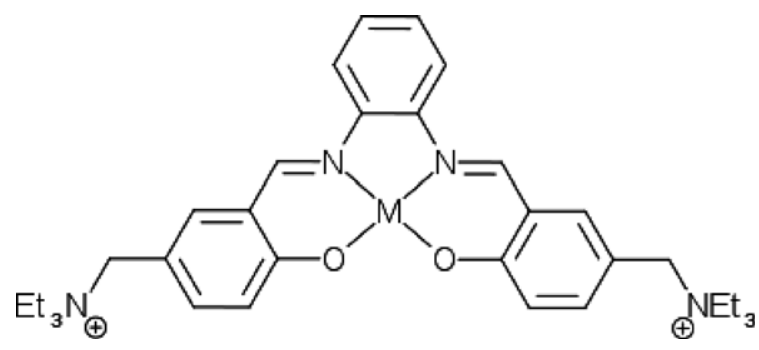

Fig. 1. Structure of the $\mathrm{ML}^{2+}$ complex $\left(\mathrm{M}=\mathrm{Zn}, \mathrm{Cu}, \mathrm{H}_{2} \mathrm{~L}^{2+}=5\right.$-triethyl ammonium methyl salicylidene orto-phenylendiimine). 
$\mathrm{ZnC}_{34} \mathrm{H}_{46} \mathrm{~N}_{4} \mathrm{O}_{10} \mathrm{Cl}_{2}\left(\mathrm{ZnL}\left(\mathrm{ClO}_{4}\right)_{2}\right)$ : (a) Anal. Calcd: C, $50.60 ; \mathrm{H}, 5.74 ; \mathrm{N}, 6.94 ; \mathrm{Cl}, 8.79$; found: $\mathrm{C}, 50.18 ; \mathrm{H}$, 5.68; N, 6.97; Cl, 8.78; (b) electronic absorption in Tris$\mathrm{HCl}, \mathrm{pH} 7.5:\left[\mathrm{nm}\left(\varepsilon, \mathrm{M}^{-1} \mathrm{~cm}^{-1}\right)\right]: 244\left(3.97 \times 10^{4}\right), 293$ $\left(1.69 \times 10^{4}\right), 373\left(1.51 \times 10^{4}\right)$; (c) ${ }^{1} \mathrm{H}$ NMR $(300.13 \mathrm{MHz}$, DMSO-D $\left._{6}\right) \delta(\mathrm{ppm}): 1.23-1.27\left(\mathrm{t}, 18 \mathrm{H}, J=6.6 \mathrm{~Hz}, \mathrm{CH}_{3}\right)$; 3.04-3.09 (q, $\left.6 \mathrm{H}, J=6.3 \mathrm{~Hz}, \mathrm{CH}_{2}\right) ; 4.25\left(\mathrm{~s}, 2 \mathrm{H}, \mathrm{CH}_{2}\right)$; 6.68-6.71 (d, $2 \mathrm{H}, J=8.7 \mathrm{~Hz}, \operatorname{Ar}) ; 7.22-7.26(\mathrm{dd}, 2 \mathrm{H}$, $J=2.1 \mathrm{~Hz}, J=9.0 \mathrm{~Hz}, \mathrm{Ar}) ; 7.36-7.39$ (m, 2H, Ar); 7.46$7.47(\mathrm{~d}, 2 \mathrm{H}, J=2.1 \mathrm{~Hz}, \mathrm{Ar}) ; 7.83-7.86(\mathrm{~m}, 2 \mathrm{H}, \mathrm{Ar}) ; 8.97$ (s, 2H, CH).

The NMR spectra were recorded on a Bruker Avance 300 spectrometer.

Lyophilized calf thymus DNA (Fluka, BioChemika) was resuspended in $1.0 \times 10^{-3} \mathrm{M}$ tris-hydroxymethyl-aminomethane (Tris- $\mathrm{HCl}) \mathrm{pH} 7.5$ and dialyzed as described in the literature [29]. DNA concentration, expressed in monomers units ([DNA $\mathrm{Dhosphate}]$ ), was determined by UV spectrophotometry using the molar absorption coefficient $7000 \mathrm{M}^{-1} \mathrm{~cm}^{-1}$ at $258 \mathrm{~nm}$ [30]. Ethidium bromide (EB) (Aldrich) was dissolved in Tris- $\mathrm{HCl}, \mathrm{pH} 7.5$.

All experiments were carried in Tris- $\mathrm{HCl}$ aqueous buffer at $\mathrm{pH}$ 7.5. Absorption measurements were performed on a Varian UV-vis Cary 1E double beam spectrophotometer, equipped with a Peltier temperature controller, using $1 \mathrm{~cm}$ path-length cuvettes. Circular dichroism (CD) spectra were recorded at $25^{\circ} \mathrm{C}$ on a Jasco J-715 spectropolarimeter, using $1 \mathrm{~cm}$ path-length quartz cells. Fluorescence spectral changes were registered, at room temperature, in the range $200-1100 \mathrm{~nm}$ on samples excited by a Deuterium lamp (Avalight-DHS) in the frequency range $200-400 \mathrm{~nm}$ using an Avaspec-2048 spectrometer.

\section{Results and discussion}

\subsection{UV-vis Absorption spectroscopy}

$\mathrm{CuL}^{2+}$ and $\mathrm{ZnL}^{2+}$ (Fig. 1) show an intense absorption band at about 252 and $244 \mathrm{~nm}$, respectively, and a characteristic absorption band at about $397 \mathrm{~nm}$ and $373 \mathrm{~nm}$, respectively. The latter can be attributed to a metal perturbed infra-ligand electronic transition. In fact, an absorption band at about $370 \mathrm{~nm}$ has been also observed in $1 \mathrm{mM}$ Tris- $\mathrm{HCl}$ aqueous solutions of the isolated ligand. Moreover, the similarity with the UV absorption spectrum of the $\mathrm{Fe}(\mathrm{III}) \mathrm{SalenCl}$ complex [31,32], recently investigated [20], allows us to infer that both the $\mathrm{Zn}(\mathrm{II})$ and $\mathrm{Cu}(\mathrm{II})$ cationic complexes analogously adopt a square planar $\mathrm{O}_{2} \mathrm{~N}_{2}$ coordination. The UV-vis absorption spectrum of both metal complexes is significantly perturbed by the addition of increasing amounts of DNA. In details, the absorption band of $\mathrm{ZnL}^{2+}$ at $373 \mathrm{~nm}$ (black line in Fig. 2a) is red shifted by about $10 \mathrm{~nm}$ and shows hypochromism of about $40 \%$. The absorption band of $\mathrm{CuL}^{2+}$ at $397 \mathrm{~nm}$ (black line in Fig. 2b) is red shifted by about $20 \mathrm{~nm}$ and shows hypochromism of about $30 \%$. Moreover, the intensity of the absorption band at $260 \mathrm{~nm}$ (black line) is lowered by the
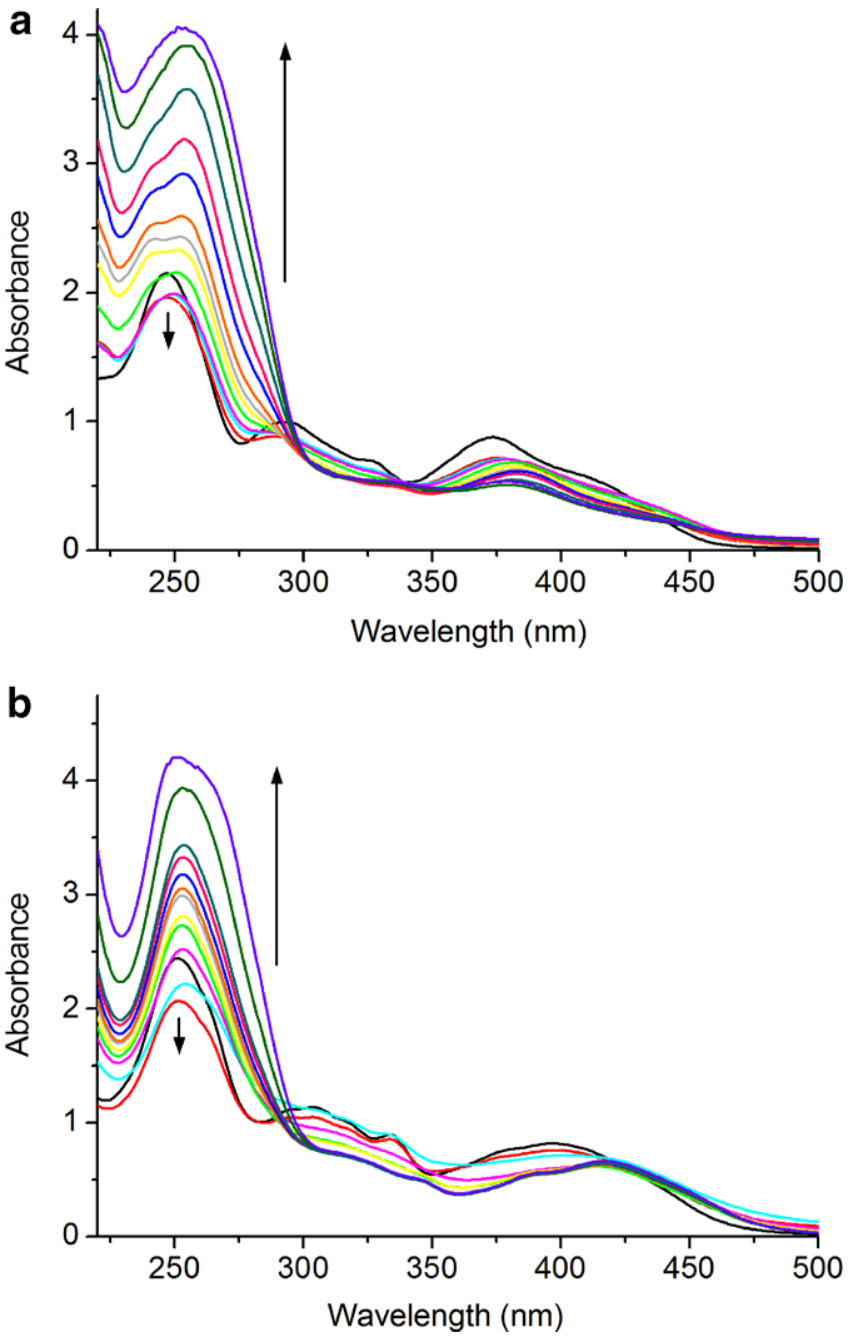

Fig. 2. Absorption spectra of $\mathrm{ZnL}^{2+}$ (a) and $\mathrm{CuL}^{2+}$ (b) in the presence of increasing amounts of CT-DNA. (a) $\left[\mathrm{ZnL}^{2+}\right]=54.0 \mu \mathrm{M}$, [DNA] $=0.0$ $(-), 27.0(-), 40.4(-), 54.0(-), 80.9(-), 107.8(-), 136.1(-), 161.8(-)$, 215.7 (-), $269.6(-), 350.5(-), 457.4(-), 540.0(-) \mu \mathrm{M} .(\mathrm{b})\left[\mathrm{CuL}^{2+}\right]=$ $52.7 \mu \mathrm{M},[\mathrm{DNA}]=0.0(-), 26.4(-), 52.7(-), 79.1(-), 105.5(-), 132.0(-)$, $158.0(-), 184.8(-), 211.6(-), 238.4(-), 263.7(-), 394.8(-), 527.5(-) \mu \mathrm{M}$.

addition of DNA up to stoichiometric ratio $\left[\mathrm{DNA}_{\text {phosphate }}\right]$ $\left[\mathrm{ML}^{2+}\right]=1.0$ for both $\mathrm{ML}^{2+}$ complexes (lines red, cyan and magenta ${ }^{1}$ for $\mathrm{ZnL}^{2+}$, Fig. 2a, lines red and cyan for $\mathrm{CuL}^{2+}$, Fig. 2b), while it increases at higher molar ratios. All these findings support the hypothesis of DNA intercalating interactions of both metal complexes [33] through the stacking interaction of the aromatic rings of the ligand and the base pairs of DNA, with a higher affinity of $\mathrm{CuL}^{2+}$ toward DNA, compared to $\mathrm{ZnL}^{2+}$.

The quantity $\left(\varepsilon_{\mathrm{a}}-\varepsilon_{\mathrm{f}}\right) /\left(\varepsilon_{\mathrm{b}}-\varepsilon_{\mathrm{f}}\right)$ at $373 \mathrm{~nm}$ for $\mathrm{ZnL}^{2+}$ and at $397 \mathrm{~nm}$ for $\mathrm{CuL}^{2+}$ has been plotted in Fig. 3, at increasing amounts of DNA. $\varepsilon_{\mathrm{a}}, \varepsilon_{\mathrm{f}}$ and $\varepsilon_{\mathrm{b}}$ are the molar extinction coefficients of the solution containing both complex and DNA, of the free complex, and of the complex bound to

\footnotetext{
${ }^{1}$ For interpretation of the references to colour in this figure legend, the reader is referred to the web version of this article.
} 

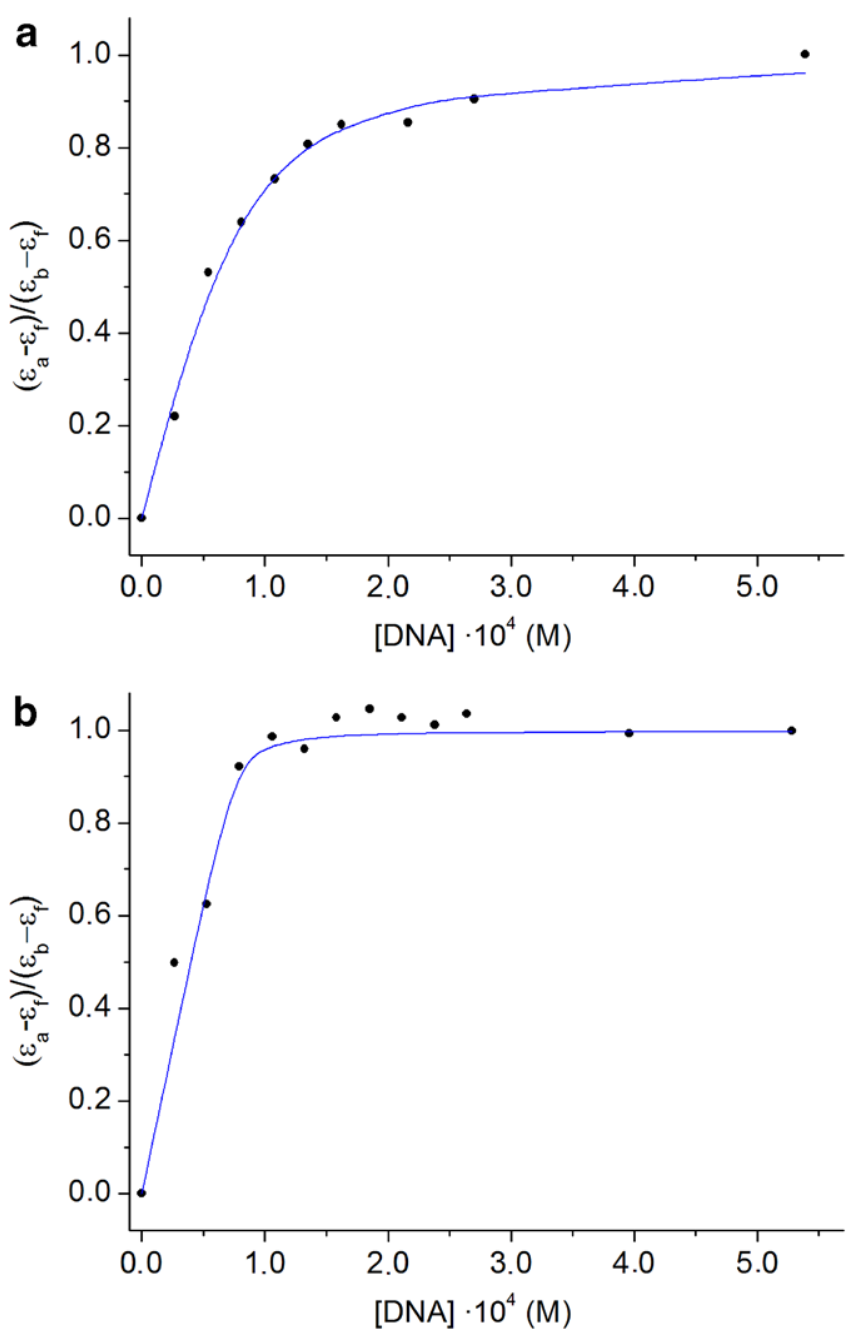

Fig. 3. Spectrophotometric titration of (a) $\mathrm{ZnL}^{2+}$, at $373 \mathrm{~nm}$, and (b) $\mathrm{CuL}^{2+}$, at $397 \mathrm{~nm}$, with CT-DNA in aqueous solution. $\left[\mathrm{ZnL}^{2+}\right]=$ $54.0 \mu \mathrm{M}, \quad[\mathrm{DNA}]=0.0-540 \mu \mathrm{M} . \quad\left[\mathrm{CuL}^{2+}\right]=52.7 \mu \mathrm{M}, \quad[\mathrm{DNA}]=0.0-$ $527.5 \mu \mathrm{M}$. The solid line is the fit of the experimental data by Eq. (1).

DNA, respectively. In particular, $\varepsilon_{\mathrm{f}}$ was determined by a calibration curve of the isolated metal complexes in aqueous solution, following the Beer-Lambert law. $\varepsilon_{\mathrm{b}}$ was determined from the plateau of the DNA titration (Fig. 3), where addition of DNA did not result in further changes in the absorption spectrum. $\varepsilon_{\mathrm{a}}$, was determined as the ratio between the measured absorbance and the $\mathrm{ML}^{2+}$ concentration.

Following Eq. (1) [34], such spectrophotometric titration allowed us to obtain the values of the intrinsic binding constant $\left(K_{\mathrm{b}}\right)$ and of the binding size in base pairs (s) of the ZnL-DNA and of the CuL-DNA complexes:

$$
\begin{aligned}
& \frac{\left(\varepsilon_{a}-\varepsilon_{f}\right)}{\left(\varepsilon_{b}-\varepsilon_{f}\right)}=\frac{\frac{b-\left(b^{2}-2 K_{\mathrm{b}}^{2} C_{\mathrm{t}}\left[\mathrm{DNA}_{\text {phosphate }}\right]\right)^{1 / 2}}{S}}{2 K_{\mathrm{b}} C_{\mathrm{t}}} \\
& b=1+K_{\mathrm{b}} C_{\mathrm{t}}+\frac{K_{\mathrm{b}}\left[\mathrm{DNA}_{\text {phosphate }}\right]}{2 s}
\end{aligned}
$$

where $C_{\mathrm{t}}$ is the total concentration of the metal complex, and $\left[\mathrm{DNA}_{\text {phosphate }}\right]$ is the DNA concentration in monomer units. The $K_{\mathrm{b}}$ and $s$ values obtained by nonlinear fits of the experimental data by Eq. (1) were $K_{\mathrm{b}}=(1.28 \pm 0.05) \times 10^{6}$ $\mathrm{M}^{-1}, s=0.73 \pm 0.05$ for $\mathrm{CuL}^{2+}, K_{\mathrm{b}}=(7.35 \pm 0.01) \times 10^{4}$ $\mathrm{M}^{-1}, s=0.69 \pm 0.01$ for $\mathrm{ZnL}^{2+}$. These results confirm that both metal complexes strongly interact with DNA and that the binding of $\mathrm{CuL}^{2+}$ to DNA is one order of magnitude tighter than that of $\mathrm{ZnL}^{2+}$. These $K_{\mathrm{b}}$ values are of the same order of magnitude of that determined in analogous conditions for $\mathrm{EB}, K_{\mathrm{b}}=1.9 \times 10^{5} \mathrm{M}^{-1}$ [5]. Moreover, the $K_{\mathrm{b}}$ value obtained for the $\mathrm{CuL}^{2+}$-DNA system is analogous to that previously determined by equilibrium dialysis and spectrophotometric methods [27], where it is reported that $\mathrm{CuL}^{2+}$ is a strong DNA intercalator. Finally, both complexes show an interaction stoichiometry of approximately $2 \mathrm{~mol}$ of DNA base pairs per 3 mol of metal complex. Similar values have been found for metal complexes-DNA systems with ascertained DNA intercalating interaction (see e.g. $[4,17])$. It has been in particular reported [4] that a value of $0.7 \mathrm{~mol}$ of base pair per mol of ligand could result from stacking of ligand molecules on the DNA surface.

\subsection{DNA thermal denaturation analysis}

Thermal denaturation profiles of calf thymus DNA solutions, in the presence of increasing amounts of $\mathrm{ZnL}^{2+}$ and $\mathrm{CuL}^{2+}$, were obtained by plotting the absorbance at $258 \mathrm{~nm}$ as a function of temperature (see Fig. 4).

It is known that when the temperature in the solution increases, the double-stranded DNA gradually dissociates into single strands; $T_{\mathrm{m}}$ is therefore defined as the temperature where half of the total base pairs is unpaired [35]. The DNA melting temperature $\left(T_{\mathrm{m}}\right)$ is strictly related to the stability of the double helix, and the interaction of chemicals with DNA may alter $T_{\mathrm{m}}$, by stabilizing or destabilizing the final complex. Moreover, it is also usually possible to obtain information on the strength of the interaction.

According to the literature [36-38] the intercalation of natural or synthesized compounds results in the stabilization of the DNA double helix, due to the stabilizing stacking interactions, followed by a considerable increase in the melting temperature of DNA. The presence of a positive charge on the intercalator should further increase the attractive interaction with the negatively charged phosphate groups and help the intercalative mechanism.

The melting temperature of DNA $100 \mu \mathrm{M}$ in Tris- $\mathrm{HCl}$ $1 \mathrm{mM}\left(53 \pm 2{ }^{\circ} \mathrm{C}\right.$, Fig. 4) increases of about 14, 17 and $26^{\circ} \mathrm{C}$, at $\left[\mathrm{ZnL}^{2+}\right] /\left[\mathrm{DNA}_{\text {phosphate }}\right]$ molar ratios $0.1,0.2$ and 0.45 (Fig. 4a) and of about 21 and $37^{\circ} \mathrm{C}$, at $\left[\mathrm{CuL}^{2+}\right] /$

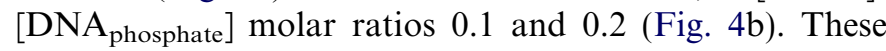
results are indicative of a strong metal complex-DNA interaction, that stabilizes the native DNA conformation. Moreover it can be argued that the stabilization, hence the complex-DNA binding, is stronger for $\mathrm{CuL}^{2+}$ compared to $\mathrm{ZnL}^{2+}$. 

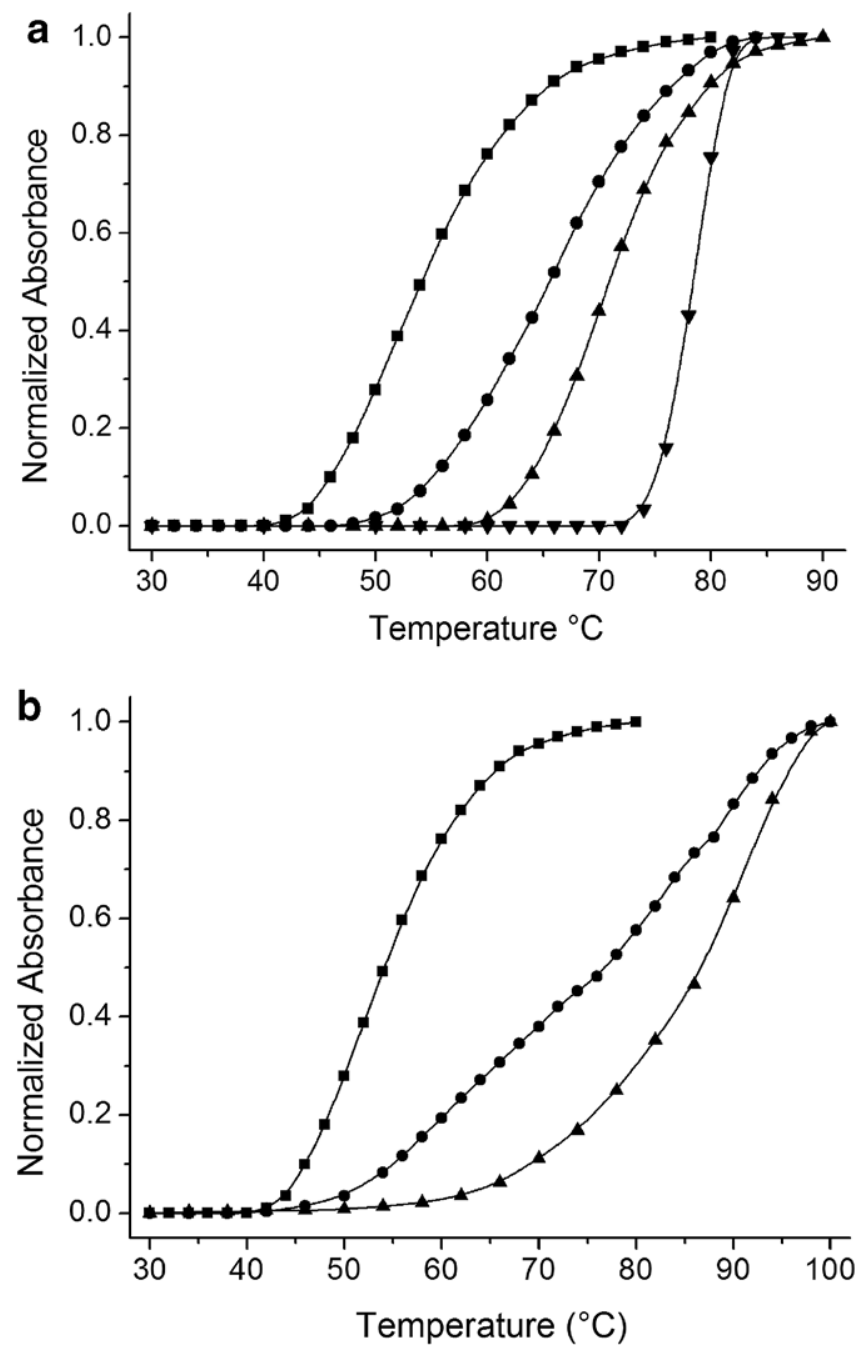

Fig. 4. Thermal denaturation profiles of CT-DNA in the presence of increasing amounts of (a) $\mathrm{ZnL}^{2+}$ and (b) $\mathrm{CuL}^{2+}$, in $1.0 \mathrm{mM}$ Tris- $\mathrm{HCl}(\mathrm{pH}$ 7.5). $\left[\mathrm{DNA}_{\text {phosphate }}\right]=100.0 \mu \mathrm{M}$; (a) $\left[\mathrm{ZnL}^{2+}\right]=0.0 \quad\left(\boldsymbol{\square}, T_{\mathrm{m}}=53^{\circ} \mathrm{C}\right)$, $10.0 \mu \mathrm{M} \quad\left(\bullet, T_{\mathrm{m}}=67^{\circ} \mathrm{C}\right), \quad 20.0 \mu \mathrm{M} \quad\left(\boldsymbol{\Lambda}, T_{\mathrm{m}}=70^{\circ} \mathrm{C}\right), 45.0 \mu \mathrm{M} \quad(\mathbf{\nabla}$, $\left.T_{\mathrm{m}}=79^{\circ} \mathrm{C}\right) ; \quad$ (b) $\left[\mathrm{CuL}^{2+}\right]=0.0 \mu \mathrm{M} \quad\left(\boldsymbol{\square}, T_{\mathrm{m}}=53^{\circ} \mathrm{C}\right), 10.0 \mu \mathrm{M} . \quad(\bullet$, $\left.T_{\mathrm{m}}=74^{\circ} \mathrm{C}\right), 20.0 \mu \mathrm{M}\left(\boldsymbol{\Delta}, T_{\mathrm{m}}=90^{\circ} \mathrm{C}\right)$.

The peculiar trend of the DNA melting profile observed in the presence of $\mathrm{CuL}^{2+}$ at $\left[\mathrm{CuL}^{2+}\right] /\left[\mathrm{DNA}_{\text {phosphate }}\right]$ molar ratios 0.1 (Fig. 4b), induces us to hypothesize that there are at least two different melting transitions involved occurring at about 65 and $85^{\circ} \mathrm{C}$. The transition at the lower temperature is no more observed in the presence of higher amounts of $\mathrm{CuL}^{2+}$ in the DNA solutions.

\subsection{Circular dichroism}

CD spectra of CT-DNA $100.0 \mu \mathrm{M}$, in $1.0 \mathrm{mM}$ Tris- $\mathrm{HCl}$ (Fig. 5), were recorded in the presence of increasing amounts of $\mathrm{ZnL}^{2+}$ and $\mathrm{CuL}^{2+}$, up to $\left[\mathrm{ML}^{2+}\right] /$ $\left[\mathrm{DNA}_{\text {phosphate }}\right]$ molar ratios approximately 0.5 .

The DNA dichroic band at ca. $275 \mathrm{~nm}$ (black line in Fig. 5a) is monotonously increased, and splitted in two bands at 264 and $287 \mathrm{~nm}$, by the addition of increasing
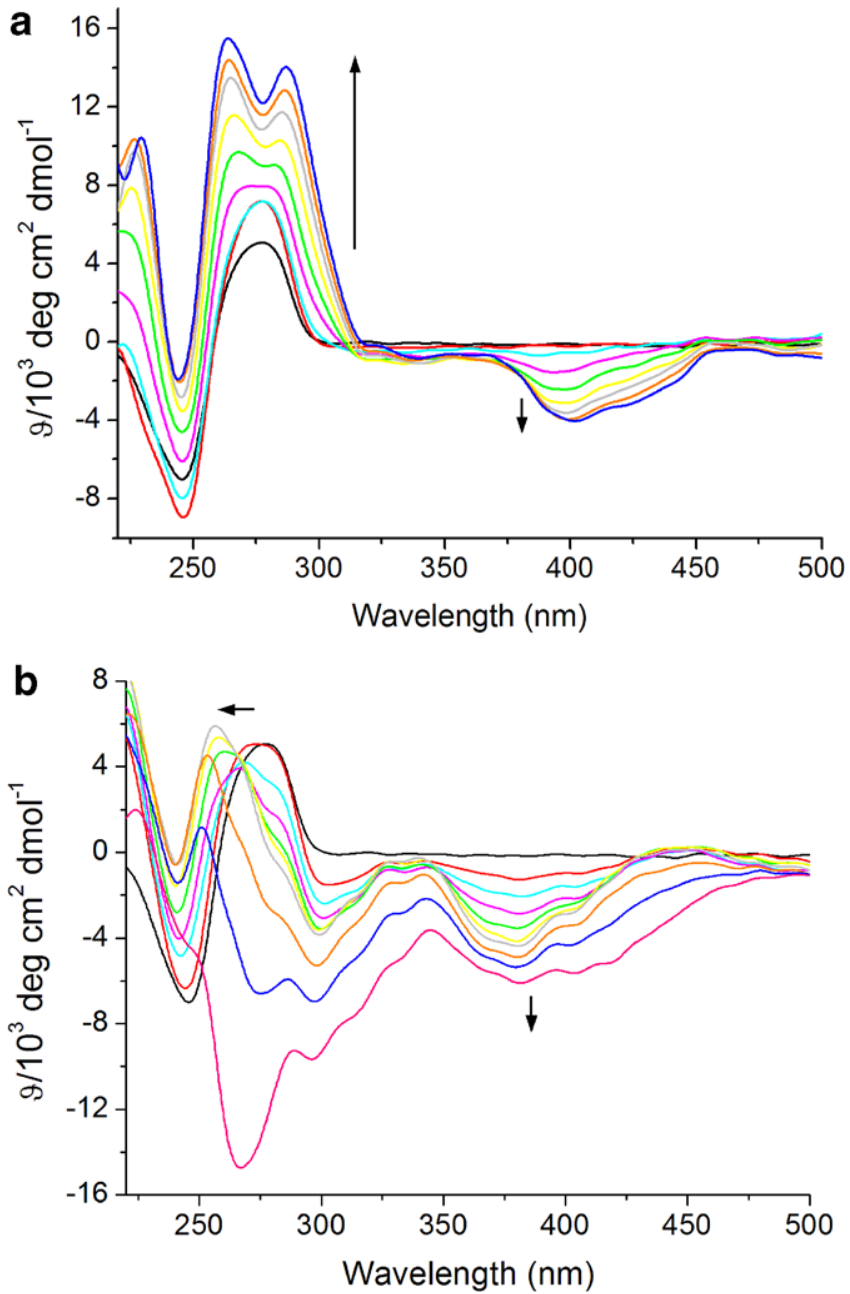

Fig. 5. Circular dichroism spectra of CT-DNA in the presence of increasing amounts of (a) $\mathrm{ZnL}^{2+}$ and (b) $\mathrm{CuL}^{2+}$, in $1.0 \mathrm{mM}$ Tris- $\mathrm{HCl}$ $(\mathrm{pH} 7.5)$. $\left[\mathrm{DNA}_{\text {phosphate }}\right]=100.0 \mu \mathrm{M}$, (a) $\left[\mathrm{ZnL}^{2+}\right]=0.0(-), 11.5(-), 17.2$ $(-), 23.0(-), 28.7(-), 34.5(-), 40.2(-), 46.0(-), 51.7(-) \mu \mathrm{M}$; (b) $\left[\mathrm{CuL}^{2+}\right]=0.0(-), 10.0(-), 15.0\left(_{(-)}, 20.0(-), 25.0(-), 30.0\left(_{(-)}, 35.0(-)\right.\right.$, $40.0(-), 45.0(-), 50.0(-) \mu \mathrm{M}$.

amounts of $\mathrm{ZnL}^{2+}$. Moreover, an induced $\mathrm{CD}$ band appears in the range $375-450 \mathrm{~nm}$. The $C D$ of native DNA (black line in Fig. 5b) is drastically modified by the addition of increasing amounts of $\mathrm{CuL}^{2+}$. In particular, a decrease and a blue shift of the positive CD band of DNA is observed and, also in this case, an induced CD band appears in the range $350-450 \mathrm{~nm}$.

These findings are indicative of deep conformational changes of the DNA double helix following the interaction of DNA macromolecule with the metal complexes. Moreover, it can be argued that a tight binding exists between the metal complexes and DNA. In fact, the presence of induced $\mathrm{CD}$ shows that both $\mathrm{ZnL}^{2+}$ and $\mathrm{CuL}^{2+}$ moieties supply a further chromofore appended to the chiral backbone of the DNA double helix [39].

Finally, the $\mathrm{CD}$ spectrum recorded in the presence of $\left[\mathrm{CuL}^{2+}\right]=50 \mu \mathrm{M}$ is similar to that observed for the condensed $\psi$-DNA forms [40]. This would indicate that the copper complex at higher concentrations induces the 

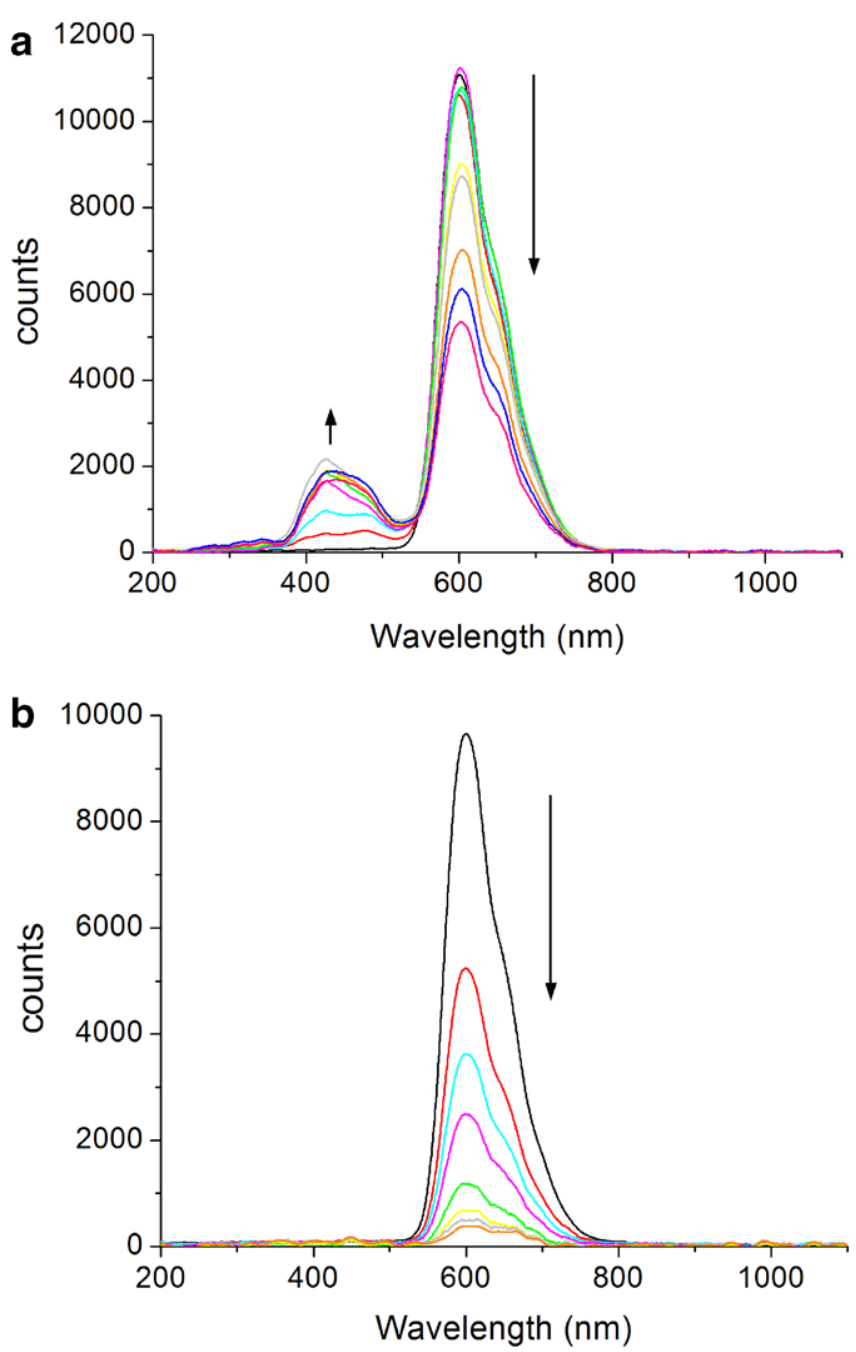

Fig. 6. Fluorescence spectra of the EB-DNA complex in the presence of increasing amounts of (a) $\mathrm{ZnL}^{2+}$ and (b) $\mathrm{CuL}^{2+}$. [EB] $=4.0 \mu \mathrm{M}$, $\left[\mathrm{DNA}_{\text {phosphate }}\right]=25.0 \mu \mathrm{M}$; (a) $\left[\mathrm{ZnL}^{2+}\right]=0.0(-), 2.5(-), 7.5(-), 10.0$ $(-), 12.5(-), 17.5(-), 20.0(-), 30.0(-), 40.0(-), 60.0(-) \mu \mathrm{M}$; (b) $\left[\mathrm{CuL}^{2+}\right]=0.0(-), 1.3(-), 1.9(-), 2.5(-), 3.8(-), 5.0(-), 6.3(-), 7.5$ $(-) \mu \mathrm{M}$.

formation of supramolecular DNA aggregates. Such results could be put in relation with the DNA melting profile recorded at $\left[\mathrm{CuL}^{2+}\right] /\left[\mathrm{DNA}_{\text {phosphate }}\right]$ molar ratio 0.1 (Fig. 4b). In fact, this would mean that in the presence of low amounts of $\mathrm{CuL}^{2+}$, two forms of DNA could be present, i.e. the non aggregate and the aggregate forms. By increasing the $\mathrm{CuL}^{2+}$ concentration, an increase of the amount of supramolecular DNA structure should occur.

\subsection{Fluorescence spectroscopic studies}

No fluorescence was observed for the $\mathrm{CuL}^{2+}$ solution, while an emission band at $440 \mathrm{~nm}$ is present in the spectrum of the $\mathrm{ZnL}^{2+}$ complex. On the other hand, it is know that CT-DNA does not give fluorescence, while its emission intensity is greatly enhanced in the presence of Ethidium bromide (EB). EB is also weakly fluorescent, but the EBDNA complex is remarkably more fluorescent at about
$600 \mathrm{~nm}$, as a consequence of the intercalation of EB between adjacent DNA base pairs [41].

The emission spectra of the EB-DNA complex in Tris$\mathrm{HCl} 1 \mathrm{mM}$, in the presence of increasing amounts of $\mathrm{ZnL}^{2+}$ and $\mathrm{CuL}^{2+}$, are shown in Fig. 6. It can be noted that the intensity of the fluorescence spectrum of the EB-DNA complex is lowered by the addition of increasing amounts of both $\mathrm{ZnL}^{2+}$ (Fig. 6a) and of $\mathrm{CuL}^{2+}$ (Fig. 6b). Both complexes then seem to displace EB from the DNA cavities. This result confirms that both complexes interact with DNA by an intercalating mechanism, competing with EB for the same binding sites.

The relative intensity values $\left(F_{0} / \mathrm{F}\right)$ at $600 \mathrm{~nm}$, of the fluorescence spectra of the EB-DNA complex in the presence of increasing amounts of $\mathrm{ZnL}^{2+}$ and of $\mathrm{CuL}^{2+}$ are reported in Fig. 7.

In Fig. 7a it is possible to distinguish two linear trends of the emission band at ca. $600 \mathrm{~nm}$ with the amount of $\mathrm{ZnL}^{2+}$,
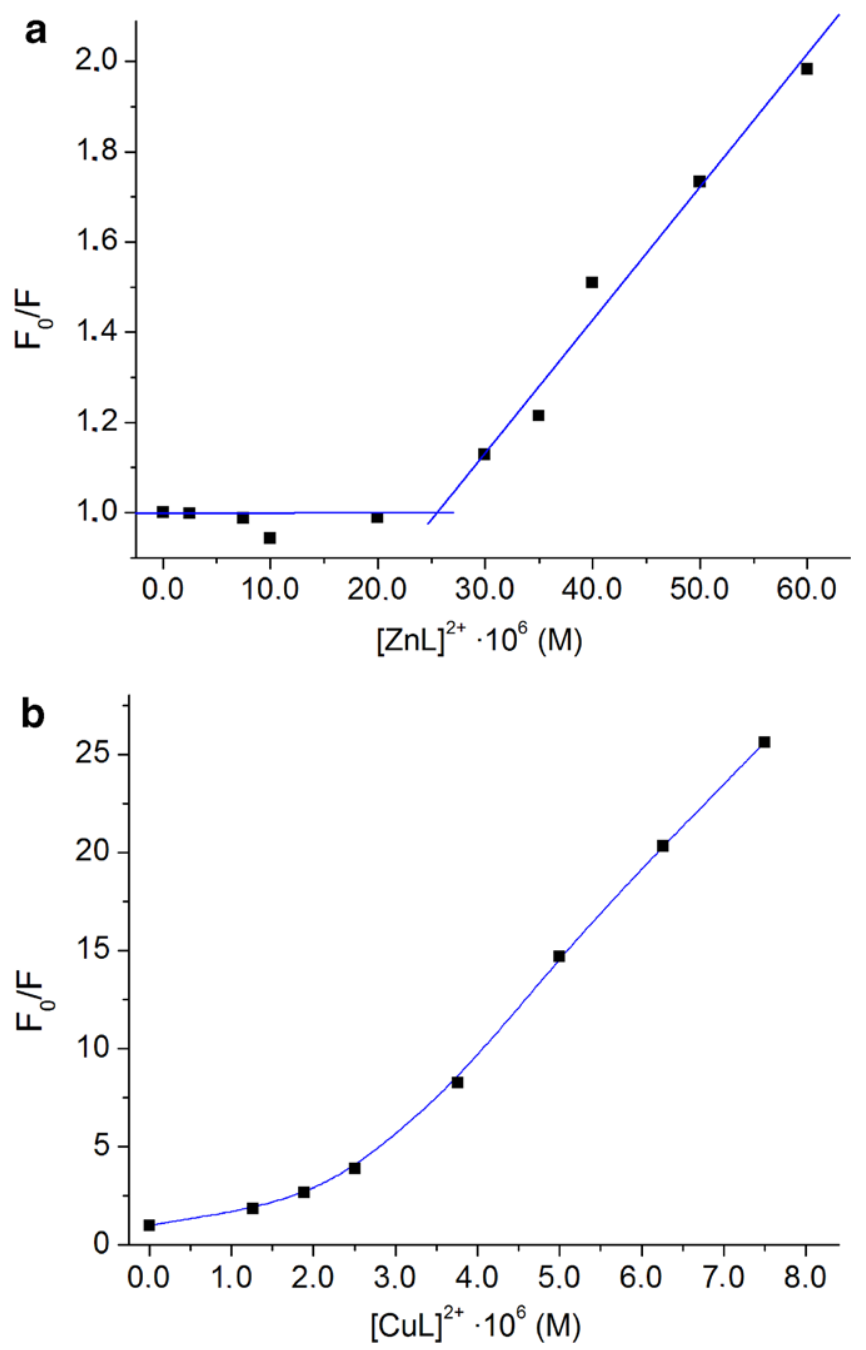

Fig. 7. Relative intensity $\left(F_{0} / \mathrm{F}\right)$ at $600 \mathrm{~nm}$, of the fluorescence spectra of the EB-DNA complex in the presence of increasing amounts of (a) $\mathrm{ZnL}^{2+}$ and (b) $\mathrm{CuL}^{2+}$. $[\mathrm{EB}]=4.0 \mu \mathrm{M},\left[\mathrm{DNA}_{\text {phosphate }}\right]=25.0 \mu \mathrm{M}$; (a) $\left[\mathrm{ZnL}^{2+}\right]=$ $0-60 \mu \mathrm{M} ;$ (b) $\left[\mathrm{CuL}^{2+}\right]=0-7.5 \mu \mathrm{M}$. 
showing that: at $\left[\mathrm{ZnL}^{2+}\right] /\left[\mathrm{DNA}_{\text {phosphate }}\right]$ molar ratios roughly less than 1, there is no evidence of EB quenching; at $\left[\mathrm{ZnL}^{2+}\right] /\left[\mathrm{DNA}_{\text {phosphate }}\right]$ molar ratios greater than 1 , the emission intensity monotonously decreases by increasing the $\mathrm{ZnL}^{2+}$ concentration.

On the other hand, Fig. $7 \mathrm{~b}$ shows that the emission band at ca. $600 \mathrm{~nm}$ monotonously decreases by increasing the amount of $\mathrm{CuL}^{2+}$ at concentrations 10 times lower than $\mathrm{ZnL}^{2+}$.

This result shows that $\mathrm{CuL}^{2+}$ is more able than $\mathrm{ZnL}^{2+}$ in replacing the strong DNA intercalator $\mathrm{EB}$, in agreement with the higher value of $K_{\mathrm{b}}$ spectrophotometrically determined (see above).

This result is consistent with a DNA intercalation mechanism for both metal complexes, being $\mathrm{CuL}^{2+}$ characterized by a higher affinity toward DNA, compared to $\mathrm{ZnL}^{2+}$.

\section{Conclusions}

The results obtained collectively show that $\mathrm{ZnL}^{2+}$ and $\mathrm{CuL}^{2+}$ strongly interact with native DNA, presumably by an intercalative mechanism. $\mathrm{CuL}^{2+}$, seems to be a stronger DNA intercalator than $\mathrm{ZnL}^{2+}$.

The interaction occurrence is supported by the following three findings:

(i) the high values of $K_{\mathrm{b}},(1.28 \pm 0.05) \times 10^{6} \mathrm{M}^{-1}$, and $(7.35 \pm 0.01) \times 10^{4} \mathrm{M}^{-1}$, obtained for $\mathrm{CuL}^{2+}$ and $\mathrm{ZnL}^{2+}$, respectively;

(ii) the noteworthy increase of the DNA melting temperature, $T_{\mathrm{m}}$, of about 14,17 and $26^{\circ} \mathrm{C}$, at $\left[\mathrm{ZnL}^{2+}\right] /$

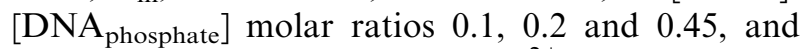
of about 21 and $37^{\circ} \mathrm{C}$, at $\left[\mathrm{CuL}^{2+}\right] /\left[\mathrm{DNA}_{\text {phosphate }}\right]$ molar ratios 0.1 and 0.2 ;

(iii) the appearance of an induced $\mathrm{CD}$ band in the range $350-450 \mathrm{~nm}$ at increasing $\left[\mathrm{ML}^{2+}\right] /\left[\mathrm{DNA}_{\text {phosphate }}\right]$ molar ratios.

On the other hand, the intercalation mechanism is supported by the following three evidences:

(i) the UV hypochromism and bathochromic shift of the absorption bands at $373 \mathrm{~nm}$ and $397 \mathrm{~nm}$, for $\mathrm{ZnL}^{2+}$ and $\mathrm{CuL}^{2+}$, respectively, in the presence of increasing amounts of DNA;

(ii) the decrease of the fluorescence band at $600 \mathrm{~nm}$ of EB-DNA solutions by the addition of increasing amounts of $\mathrm{ML}^{2+}$ complexes;

(iii) the pronounced modifications of the CD of DNA in the presence of increasing amounts of both $\mathrm{ML}^{2+}$ complexes.

Finally, it is worth mentioning that the shape of the CD of the $\mathrm{CuL}^{2+}-\mathrm{DNA}$ solutions, at the highest $\left[\mathrm{CuL}^{2+}\right] /$ $\left[\mathrm{DNA}_{\text {phosphate }}\right]$ molar ratios investigated, is indicative of the formation of DNA aggregates.

\section{Acknowledgements}

Financial support from Università di Palermo is gratefully acknowledged.

\section{References}

[1] A.M. Pyle, J.K. Barton, in: S.J. Lippard (Ed.), Progress in Inorganic Chemistry: Bioinorganic Chemistry, vol. 38, John Wiley \& Sons, Inc., 1990, pp. 413-475.

[2] C.M. McIntosh, E.A. Esposito III, A.K. Boal, J.M. Simard, C.T. Martin, V.M. Rotello, J. Am. Chem. Soc. 123 (2001) 7626-7629.

[3] W. Chu, M. Shinomiya, K.Y. Kamitori, S. Kamitori, R.G. Carlson, R.F. Weaver, F. Takusagawa, J. Am. Chem. Soc. 116 (1994) 79717982.

[4] I. Haq, P. Lincoln, D. Suh, B. Norden, J.B. Chowdhry, J. Chaires, J. Am. Chem. Soc. 117 (1995) 4788-4796.

[5] P.K.-L. Fu, P.M. Bradley, C. Turro, Inorg. Chem. 42 (2003) 878-884.

[6] M.J. Kendrick, M.T. May, M.J. Plishka, K.D. Robinson, in: J. Burgess (Ed.), Metals in biological Systems, Ellis Horwood, London, 1992, pp. 83-86 (pp. 142-149).

[7] T. Biver, F. Secco, M.R. Tinè, M. Venturini, A. Bencini, A. Bianchi, C. Giorni, J. Inorg. Biochem. 98 (2004) 1531-1538.

[8] M.E. Anderson, A.G.M. Barret, B.M. Hoffman, J. Inorg. Biochem. 80 (2000) 257-260.

[9] D.H. Tjahjono, S. Mima, T. Akutsu, N. Yoshioka, H. Inoue, J. Inorg. Biochem. 85 (2001) 219-228.

[10] M. Navarro, E.J. Cisneros-Fajardo, A. Sierralta, M. FernandezMestre, P. Silva, D. Arrieche, E. Marchan, J. Inorg. Biochem. 97 (2003) 364-369.

[11] M. Gonzàles-Alvarez, G. Alzuet, J. Borràs, M. Pitiè, B. Meunier, J. Biol. Inorg. Chem. 8 (2003) 644-652.

[12] M. Lainè, F. Richard, E. Tarnaud, C. Bied-Charreton, C. VerchèreBèaur, J. Biol. Inorg. Chem. 9 (2004) 550-562.

[13] M. Baldini, M. Belicchi-Ferrari, F. Risceglie, G. Pelosi, S. Pinelli, P. Tarasconi, Inorg. Chem. 42 (2003) 2049-2055.

[14] A. Sigel, H. Sigel (Eds.), Metal Ions in Biological Systems, vol. 32, Marcel Dekker, New York, 1996.

[15] K.E. Erkkila, T.D. Odom, J.K. Barton, Chem. Rev. 99 (1999) $2777-$ 2795.

[16] C. Metcalfe, J.A. Thomas, Chem. Soc. Rev. 32 (2003) 215-224.

[17] R.B. Nair, E.S. Teng, S.L. Kirkland, C.J. Murphy, Inorg. Chem. 37 (1998) 139-141.

[18] M. Cusumano, M.L. Di Pietro, A. Giannetto, P.A. Vainiglia, J. Inorg. Biochem. 99 (2005) 560-565.

[19] A. Juris, F. Balzani, S. Barigelletti, S. Campagna, P. Belser, A. von Zelewsky, Coordin. Chem. Rev. 84 (1988) 85-277.

[20] A. Silvestri, G. Barone, G. Ruisi, M.T. Lo Giudice, S. Tumminello, J. Inorg. Biochem. 98 (2004) 589-594.

[21] K. Sato, M. Chikira, Y. Fujii, A. Komatsu, J. Chem. Soc. Chem. Commun. (1994) 625-626.

[22] L.-Z. Li, C. Zhao, T. Xu, H.-W. Ji, Y.-H. Yu, G.-Q. Guo, H. Chao, J. Inorg. Biochem. 99 (2005) 1076-1082.

[23] D.J. Gravert, J.H. Griffin, Inorg. Chem. 35 (1996) 4837-4847.

[24] S. Routier, J.-L. Bernier, M.J. Waring, P. Colson, C. Houssier, C. Bailly, J. Org. Chem. 61 (1996) 2326-2331.

[25] J.G. Muller, L.A. Kayser, S.J. Paikoff, V. Duarte, N. Tang, R.J. Perez, S.E. Rokita, C.J. Burrows, Coordin. Chem. Rev. 185-186 (1999) 761-774.

[26] C.-C. Cheng, Y.L. Lu, J. Chin. Chem. Soc. 45 (1998) 611-617.

[27] T. Tanaka, K. Tsurutani, A. Komatsu, T. Ito, K. Iida, Y. Fujii, Y. Nakano, Y. Usui, Y. Fukuda, M. Chikira, Bull. Chem. Soc. Jpn. 70 (1997) 615-629.

[28] S.J. Angyal, P.J. Morris, J.R. Tetaz, J.G. Wilson, J. Chem. Soc. (1950) 2141-2145.

[29] P. McPhie, Methods Enzymol. 22 (1971) 23-32.

[30] S.D. Kennedy, R.G. Bryant, Biophys. J. 50 (1986) 669-676. 
[31] F. Lloret, J. Moratal, J. Faus, J. Chem. Soc., Dalton Trans. (1983) $1743-1748$.

[32] Y.W. Liou, C.M. Wang, J. Electroanal. Chem. 481 (2000) 102-109.

[33] T. Uno, K. Hamasaki, M. Tanigawa, S. Shimabayashi, Inorg. Chem. 36 (1997) 1676-1683.

[34] M.T. Carter, M. Rodriguez, A. Bard, J. Am. Chem. Soc. 111 (1989) 8901-8911.

[35] Y.-J. Liu, H. Chao, L.-F. Tau, Y.-X. Yuan, W. Wei, L.-N. Ji, J. Inorg. Biochem. 99 (2005) 530-537.

[36] M.J. Waring, J. Mol. Biol. 13 (1965) 269-274.
[37] J.M. Kelly, A.B. Tossi, D.J. McConell, C. OhUigin, Nucleic Acids Res. 13 (1985) 6017-6034.

[38] G.A. Neyhart, N. Grover, S.R. Smith, W.A. Kalsbeck, T.A. Fairly, M. Cory, H.H. Thorp, J. Am. Chem. Soc. 115 (1993) 4423-4428.

[39] M.J. Carvlin, N. Datta-Gupta, R.J. Fiel, Biochem. Biophys. Res. Commun. 108 (1982) 66-73.

[40] J.E.B. Ramos Jr., R. de Vries, J. Ruggiero Neto, J. Phys. Chem. B 109 (2005) 23661-23665.

[41] F.J. Meyer-Almes, D. Porschke, Biochemistry 32 (1993) 42464253. 